\title{
Global peroxyacetyl nitrate (PAN) retrieval in the upper troposphere from limb emission spectra of the Michelson Interferometer for Passive Atmospheric Sounding (MIPAS)
}

\author{
N. Glatthor ${ }^{1}$, T. von Clarmann ${ }^{1}$, H. Fischer ${ }^{1}$, B. Funke ${ }^{2}$, U. Grabowski ${ }^{1}$, M. Höpfner ${ }^{1}$, S. Kellmann ${ }^{1}$, A. Linden ${ }^{1}$, \\ M. Milz ${ }^{1}$, T. Steck ${ }^{1}$, and G. P. Stiller ${ }^{1}$ \\ ${ }^{1}$ Forschungszentrum Karlsruhe, Institut für Meteorologie und Klimaforschung, Karlsruhe, Germany \\ ${ }^{2}$ Instituto de Astrofísica de Andalucía (CSIC), Granada, Spain
}

Received: 6 December 2006 - Published in Atmos. Chem. Phys. Discuss.: 29 January 2007

Revised: 14 May 2007 - Accepted: 21 May 2007 - Published: 4 June 2007

\begin{abstract}
We use limb emission spectra of the Michelson Interferometer for Passive Atmospheric Sounding (MIPAS) onboard the ENVIronmental SATellite (ENVISAT) to derive the first global distribution of peroxyacetyl nitrate (PAN) in the upper troposphere. PAN is generated in tropospheric air masses polluted by fuel combustion or biomass burning and acts as a reservoir and carrier of $\mathrm{NO}_{\mathrm{x}}$ in the cold free troposphere. PAN exhibits continuum-like broadband structures in the mid-infrared region and was retrieved in a contiguous analysis window covering the wavenumber region 775 $800 \mathrm{~cm}^{-1}$. The interfering species $\mathrm{CCl}_{4}, \mathrm{HCFC}-22, \mathrm{H}_{2} \mathrm{O}$, $\mathrm{ClONO}_{2}, \mathrm{CH}_{3} \mathrm{CCl}_{3}$ and $\mathrm{C}_{2} \mathrm{H}_{2}$ were fitted along with PAN, whereas pre-fitted profiles were used to model the contribution of other contaminants like ozone. Sensitivity tests consisting in retrieval without consideration of PAN demonstrated the existence of PAN signatures in MIPAS spectra obtained in polluted air masses. The analysed dataset consists of 10 days between 4 October and 1 December 2003. This period covers the end of the biomass burning season in South America and South and East Africa, in which generally large amounts of pollutants are produced and distributed over wide areas of the southern hemispheric free troposphere. Indeed, elevated PAN amounts of 200-700 pptv were measured in a large plume extending from Brasil over the Southern Atlantic, Central and South Africa, the South Indian Ocean as far as Australia at altitudes between 8 and $16 \mathrm{~km}$. Enhanced PAN values were also found in a much more restricted area between northern subtropical Africa and India. The most significant northern midlatitude PAN signal was detected in an area at $8 \mathrm{~km}$ altitude extending from China into the Chinese Sea. The average mid and high latitude PAN amounts found at $8 \mathrm{~km}$ were around $125 \mathrm{pptv}$ in the northern, but only be-
\end{abstract}

Correspondence to: N. Glatthor

(norbert.glatthor@imk.fzk.de) tween 50 and 75 pptv in the southern hemisphere. The PAN distribution found in the southern hemispheric tropics and subtropics is highly correlated with the jointly fitted acetylene $\left(\mathrm{C}_{2} \mathrm{H}_{2}\right)$, which is another pollutant produced by biomass burning, and agrees reasonably well with the $\mathrm{CO}$ plume detected during end of September 2003 at the $275 \mathrm{hPa}$ level $(\sim 10 \mathrm{~km})$ by the Measurement of Pollution in the Troposphere (MOPITT) instrument on the Terra satellite. Similar southern hemispheric PAN amounts were also observed by previous airborne measurements performed in September/October 1992 and 1996 above the South Atlantic and the South Pacific, respectively.

\section{Introduction}

Peroxyacetyl nitrate (PAN) is generated in air masses polluted by fuel emissions or by biomass burning and is a possible indicator of photochemical smog. Its production is initialized by the reaction of hydrocarbons with the hydroxyl radical $(\mathrm{OH})$ and subsequently with $\mathrm{O}_{2}$ to form the peroxyacetyl radical $\mathrm{CH}_{3} \mathrm{C}(\mathrm{O}) \mathrm{OO}$ as specific intermediate. The reversible reaction of the peroxyacetyl radical with nitrogen dioxide produces PAN

$\mathrm{CH}_{3} \mathrm{C}(\mathrm{O}) \mathrm{OO}+\mathrm{NO}_{2} \rightleftharpoons \mathrm{CH}_{3} \mathrm{C}(\mathrm{O}) \mathrm{OONO}_{2}$.

PAN was first detected in the Los Angeles area during smog episodes (Stephens et al., 1956). Phytotoxic episodes with PAN amounts of more than 15 ppbv were observed in Southern California in the 1980s (Temple et al., 1983). Even higher amounts of more than $30 \mathrm{ppbv}$ were measured in 1997 in Mexico City (Gaffney et al., 1999). Since the 1980s PAN production has decreased in North America and Europe, but increased in Eastern Asia. The PAN amounts in clean air areas are generally substantially lower, namely between 50 and

Published by Copernicus Publications on behalf of the European Geosciences Union. 
100 pptv (Singh et al., 2000a). Widespread southern hemispheric PAN pollution extending from South America over the South Atlantic, East and South Africa, the Southern Indian Ocean as far as Australia has been observed during the annual biomass burning period in South America and South Africa in September and October (Singh et al., 1996, 2000a).

The thermal decomposition rate of PAN is highly temperature dependent, resulting in lifetimes between $1 \mathrm{~h}$ at $298 \mathrm{~K}$ and about 5 months at $250 \mathrm{~K}$ (Singh, 1987). However, due to photolysis its mean lifetime is restricted to 3 months. Because of its temperature sensitivity PAN can only be transported over a few hundred kilometres in the lower troposphere, but over distances of more than $10000 \mathrm{~km}$ in the cold upper troposphere (Singh, 1987). Thus it serves as a reservoir and carrier of $\mathrm{NO}_{\mathrm{x}}$ in this height region. When these polluted air masses warm up, PAN is destroyed and $\mathrm{NO}_{2}$ is released (Eq. 1), which is photolysed at wavelengths less than $420 \mathrm{~nm}$. This leads to formation of nitric oxide (NO) and atomic oxygen:

$\mathrm{NO}_{2}+h v(\lambda<420 \mathrm{~nm}) \longrightarrow \mathrm{NO}+\mathrm{O}$,

Subsequently, atomic oxygen reacts with $\mathrm{O}_{2}$ and produces tropospheric ozone:

$\mathrm{O}+\mathrm{O}_{2}+\mathrm{M} \longrightarrow \mathrm{O}_{3}+\mathrm{M}$.

Thus, PAN can contribute to the pollution of remote clean air areas, but has also strong influence on the oxidising power of the atmosphere. After photolytic destruction during daytime re-formation of PAN at night is possible. The fact, that contrary to ozone it has no important natural sources in the stratosphere, is an advantage of PAN over ozone as indicator of upper tropospheric hydrocarbon- $\mathrm{NO}_{\mathrm{x}}$ photochemistry (Singh, 1987).

Up to now there exists no global dataset of uppertropospheric PAN. Only a few airborne campaigns covering supra-regional areas have been performed in the free troposphere, e.g. the Global Tropospheric Experiment/Transport and Atmospheric Chemistry Near the Equator-Atlantic (GTE/TRACE A) experiment above the Tropical and South Atlantic (Singh et al., 1996) and the Pacific Exploratory Mission (PEM) Tropics-A campaign above the Pacific (Singh et al., 2000a). These missions were dedicated to study the extent and composition of the southern hemispheric biomass burning plume during September/October 1992 and 1996, respectively. Another airborne campaign off the west coast of North America, the Intercontinental Transport and Chemical Transformation 2002 (ITCT 2K2) project, was carried out to investigate the intercontinental PAN transport from East Asia (Roberts et al., 2004). Most of the other PAN data available are groundbased measurements in the boundary layer in highly polluted as well as very remote regions (Temple et al., 1983; Beine et al., 2000; Gaffney et al., 1999; Jacobi et al., 1999). Whereas all these airborne and groundbased measurements employed in-situ techniques, only quite recently the first detection of upper-tropospheric PAN in infrared remote sensing spectra of MIPAS/ENVISAT and of the balloon-borne MIPAS instrument (MIPAS-B2) was reported (Allen, 2005a; Remedios et al., 2006, 2007). The MIPAS-B2 instrument is described in Fischer and Oelhaf (1996) and in Friedl-Vallon et al. (2004).

In this paper we present the first global distribution of PAN derived from spaceborne mid infra-red emission spectra. In detail, we will describe the retrieval method, give an error estimation, discuss sensitivity tests, and present the global PAN distribution observed between 4 October and 1 December 2003. This period covers the end of the biomass burning season in South America, Central and South Africa and in Australia. Thus, a widespread distribution of elevated PAN amounts and of other pollutants was expected in the southern hemispheric tropical and subtropical upper troposphere. While this paper is focused on the description of the PAN retrieval scheme and on the presentation of the retrieved PAN distribution, a more detailed investigation of the biomass burning plume by combined analysis of several pollutants and by trajectory calculations will be presented in a subsequent paper.

\section{Michelson Interferometer for Passive Atmospheric Sounding}

The Michelson Interferometer for Passive Atmospheric Sounding (MIPAS) was launched onboard the Sunsynchronous polar-orbiting European ENVIronmental SATellite (ENVISAT) on 1 March 2002. It is a limb-viewing Fourier transform infrared (FTIR) emission spectrometer covering the mid-infrared spectral region from 685 to $2410 \mathrm{~cm}^{-1}$. Its wide spectral coverage and high spectral resolution, which is $0.035 \mathrm{~cm}^{-1}$ (unapodised) for spectra of the original full resolution measurement mode evaluated here, enables simultaneous observation of numerous trace gases (Fischer and Oelhaf, 1996; European Space Agency (ESA), 2000). This measurement mode consists of rearward limb-scans covering tangent altitudes between about 6 and $68 \mathrm{~km}$ within 17 altitude steps. The step-width is $3 \mathrm{~km}$ up to $42 \mathrm{~km}$ and increases up to $8 \mathrm{~km}$ above $52 \mathrm{~km}$. The level-1B radiance spectra used for PAN retrieval are data versions 4.61-4.62 provided by the European Space Agency (ESA) (Nett et al., 2002). Several data processors, amongst others one at the Institut für Meteorologie und Klimaforschung (IMK), have been developed for near-real time and off-line retrieval of profiles of atmospheric trace species from level-1B MIPAS spectra (von Clarmann et al., 2003a). The PAN distribution presented in this paper was produced with the retrieval processor of the IMK, which was developed to produce consistent datasets containing considerably more trace species than included in the operational dataset provided under ESA responsibility. 


\section{Retrieval method and error estimation}

The retrievals performed with the IMK data processor consist of inversion of MIPAS level-1B spectra to vertical profiles of atmospheric state parameters by constrained non-linear least squares fitting (e.g., Rodgers, 2000, and references therein) in a global-fit approach:

$$
\begin{aligned}
\boldsymbol{x}_{i+1}= & \boldsymbol{x}_{i}+\left(\mathbf{K}^{T} \mathbf{S}_{y}^{-1} \mathbf{K}+\mathbf{R}+\lambda \mathbf{I}\right)^{-1} \\
& \times\left(\mathbf{K}^{T} \mathbf{S}_{y}^{-1}\left(\boldsymbol{y}_{\text {meas }}-\boldsymbol{y}\left(\boldsymbol{x}_{i}\right)\right)-\mathbf{R}\left(\boldsymbol{x}_{i}-\boldsymbol{x}_{a}\right)\right),
\end{aligned}
$$

where $\boldsymbol{x}_{i+1}$ is the vector of the unknown state parameters calculated in iteration $i+1, \boldsymbol{y}_{\text {meas }}$ is the measurement vector, and $\boldsymbol{y}\left(\boldsymbol{x}_{i}\right)$ is the result of the radiative transfer model using the parameters $\boldsymbol{x}_{i}$ of iteration number $i$. $\mathbf{S}_{y}$ is the measurement noise covariance matrix, $\mathbf{K}$ is the Jacobian matrix containing the partial derivatives $\partial \boldsymbol{y}\left(\boldsymbol{x}_{i}\right) / \partial \boldsymbol{x}_{i}, \mathbf{R}$ is a regularization matrix, $\lambda \mathbf{I}$ (scalar times unity matrix) is a damping term as proposed by Levenberg (1944) and Marquardt (1963), and $\boldsymbol{x}_{a}$ is an a-priori profile used to constrain the retrieval result. To avoid any influence on the shape of the retrieved PAN profiles, an all-zero a-priori profile is chosen, whereas a midlatitude PAN profile of the Model for OZone And Related chemical Tracers (MOZART) (Horowitz et al., 2003) is used as first-guess. Application of a smoothing constraint is necessary to attenuate instabilities, because the retrieval grid used has an altitude spacing of $1 \mathrm{~km}$ up to $44 \mathrm{~km}$ and of $2 \mathrm{~km}$ between 44 and $70 \mathrm{~km}$, which means oversampling in comparison with the height distance between the tangent altitudes. Similar as in other retrievals of MIPAS data performed at IMK, Tikhonov's regularization scheme is used with a first derivative operator as constraint (Steck, 2002, and references therein).

Radiative transfer calculations are performed with the Karlsruhe Optimized and Precise Radiative Algorithm (KOPRA) (Stiller, 2000). Prior to PAN many other trace species are evaluated in the retrieval chain. First, spectral shift, the temperature profile and the tangent heights are fitted. Thereafter various trace gas profiles are retrieved in a successive manner, in which the major species $\mathrm{H}_{2} \mathrm{O}, \mathrm{O}_{3}, \mathrm{CH}_{4}$, $\mathrm{N}_{2} \mathrm{O}$, and $\mathrm{HNO}_{3}$ are analysed first. The fitted profiles of all these species are used to model their radiative contribution in the PAN retrieval unless they are joint-fitted again. Beside each target species, one continuum profiles and one heightindependent zero level calibration corrections are jointly fitted for each microwindow. The retrieval strategy is described in more detail in, e.g., von Clarmann et al. (2003b), Glatthor et al. (2004) and Höpfner et al. (2004) and references therein. Cloud-flagging, i.e. removal of cloud-contaminated spectra prior to retrieval, is performed following the standard method applied at IMK, using a threshold of 4.0 (Glatthor et al., 2006).

Since PAN is a relatively heavy and complex molecule (141 atomic mass units), the line positions are very dense and the line wings of its single rotational-vibrational transition lines overlap, which leads to broadband continuum-like

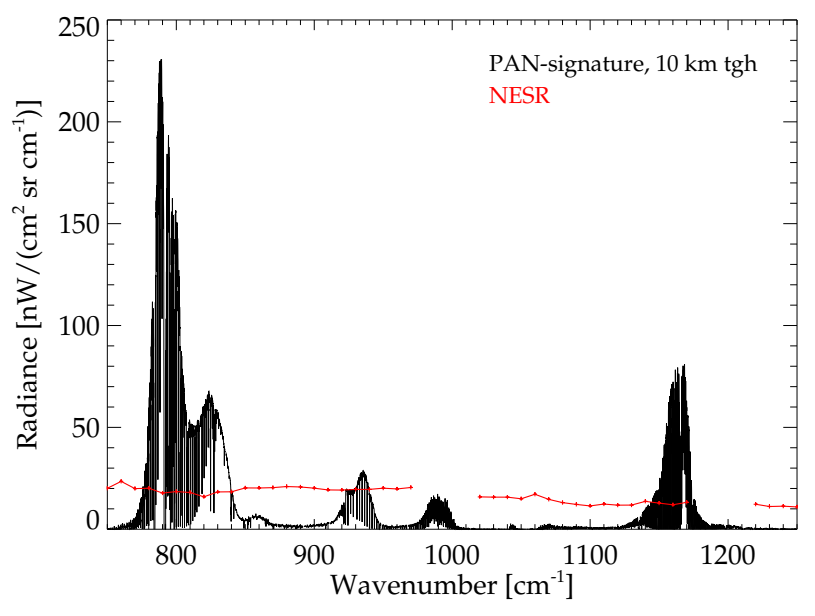

Fig. 1. PAN signatures at $10 \mathrm{~km}$ altitude (black), displayed as difference spectrum between model calculations for a tropical atmosphere containing a PAN amount of $\sim 200 \mathrm{pptv}$ (at $10 \mathrm{~km}$ ) and for a tropical PAN-free atmosphere. The main features are the bands centred at $794,930,991$ and $1163 \mathrm{~cm}^{-1}$. The red curves show the typical noise-equivalent spectral radiance (NESR) in MIPAS spectra from channels $\mathrm{A}, \mathrm{AB}$ and $\mathrm{B}$ (only low-wavenumber edge).

signatures. For this reason spectroscopic data are available as tabulated absorption cross sections only. In our retrievals PAN is modelled using a cross section dataset provided by the University of Leicester, which consists of measurements at three temperatures, 250, 273 and $295 \mathrm{~K}$, with a nominal unapodised spectral resolution of $0.25 \mathrm{~cm}^{-1}$ (Allen et al., $2005 \mathrm{~b}, \mathrm{c}$ ). Based on model calculations for a climatological tropical atmosphere, the most prominent atmospheric PAN band is that centred at $794 \mathrm{~cm}^{-1}$ (the $v_{16} \mathrm{NO}_{2}$ stretch), followed by a second band at $1163 \mathrm{~cm}^{-1}$ (the $v_{10} \mathrm{C}-\mathrm{O}$ stretch) and other considerably weaker bands. Figure 1 shows the difference spectrum for a tangent altitude of $10 \mathrm{~km}$ between an atmosphere containing a PAN amount of $\sim 200 \mathrm{pptv}$ (at $10 \mathrm{~km})$ and a PAN-free atmosphere. Comparison with the noise-equivalent spectral radiance (NESR) of MIPAS indicates that for this PAN amount a signal-to-noise ratio of larger than $10 \mathrm{can}$ be obtained in the band at $794 \mathrm{~cm}^{-1}$. After test of different sizes of the analysis window, PAN retrievals were finally performed in one contiguous microwindow in the wavenumber region $775-800 \mathrm{~cm}^{-1}$, which covers the strongest signatures of the band at $794 \mathrm{~cm}^{-1}$. Due to the large amount of MIPAS data to be analysed, the weaker part of this band between 800 and $830 \mathrm{~cm}^{-1}$ as well as the band at $1163 \mathrm{~cm}^{-1}$ were not used for retrieval to save computation time. However some sample consistency tests were performed, in which the whole band at $794 \mathrm{~cm}^{-1}$ as well as the band at $1163 \mathrm{~cm}^{-1}$ were evaluated. For correct modelling of the $\mathrm{CO}_{2}$ Q-branch at $792 \mathrm{~cm}^{-1}$ radiative transfer calculations were performed with inclusion of $\mathrm{CO}_{2}$ line-mixing. Because of its relatively weak signal and broadband structure, PAN requires a careful retrieval to separate its signature from the 
atmospheric continuum and from other broadband species, namely $\mathrm{CCl}_{4}, \mathrm{HCFC}-22, \mathrm{ClONO}_{2}$ and $\mathrm{CH}_{3} \mathrm{CCl}_{3}$, which also contribute to the atmospheric signal in this spectral interval. Thus, beside PAN these species as well as $\mathrm{H}_{2} \mathrm{O}$ and $\mathrm{C}_{2} \mathrm{H}_{2}$, one continuum profile and one height-independent offset (one microwindow only) were also fitted. The results of preceding retrievals were used to model the temperature profile and the contribution of other interfering species like ozone, because test calculations had demonstrated that jointfit of these species had only little influence on the retrieved PAN profile.

Figure 2 shows a PAN profile obtained on 21 October, 2003, over Eastern Africa (top left) and another profile from the same orbit obtained above northern midlatitudes (top right). Over East Africa a PAN volume mixing ratio (vmr) as high as 700 pptv was detected at the lowermost height useable for retrieval at this geolocation $(11 \mathrm{~km}$, due to clouds). Towards higher altitudes PAN decreases to $65 \mathrm{pptv}$ at the tropopause $(17 \mathrm{~km})$ and to $50 \mathrm{pptv}$ at $20 \mathrm{~km}$. The midlatitude profile exhibits PAN values of $\sim 175$ pptv in the troposphere, a rapid decrease at the tropopause and also values around $50 \mathrm{pptv}$ in the lowermost stratosphere. The corresponding averaging kernels (middle panels) indicate, that at the tropical geolocation a PAN signal is obtainable between 11 and $23 \mathrm{~km}$ and at the midlatitude geolocation, which is not contaminated by clouds, between 5 and $23 \mathrm{~km}$. The calculated number of degrees of freedom is 2.4 for the tropical and 4.6 for the midlatitude geolocation. The higher midlatitude value is due to higher temperatures between 11 and $25 \mathrm{~km}$ and further extension of the scan into the troposphere. In both cases the height resolution is $3.5-6 \mathrm{~km}$ (degrading with altitude). The averaging kernels show that the PAN amounts retrieved in the lowermost stratosphere have a certain tropospheric contribution. Nevertheless, these PAN values are in good agreement with PAN amounts reported by Singh et al. (2000b) for the lower stratosphere above the Northern Atlantic (solid red squares).

The diagrams at the bottom of Fig. 2 show the total estimated PAN retrieval error, measurement noise and the major error components for both geolocations, in which all error components are 1-sigma uncertainties. The error estimation is based on the actual retrieved temperatures, tangent heights, PAN profiles and simulated spectra and Jacobians of the final iteration (cf. Glatthor et al., 2004). The error contributions displayed for the tropical (left) and midlatitude geolocation (right) are not exactly the same, because due to different atmospheric conditions slightly different components proved important (only components larger than $2 \%$ or $4 \%$, respectively, are shown). The meaning of the various error sources listed in the legend is the following: total: total retrieval error; noise: measurement noise; param: total contribution of all error components except of noise; o3, hno3, cof2, co2: errors due to uncertain knowledge on the respective trace gases; tem, los, tgra: errors due to uncertainty in the temperature profile, in instrumental pointing and in the horizontal temperature gradient $(1 \mathrm{~K}, 150 \mathrm{~m}$ and $1 \mathrm{~K} / 100 \mathrm{~km}$ assumed, respectively); spectro, shift, gain, ils: errors caused by uncertain knowledge on PAN spectroscopic data, frequency calibration, gain calibration and on instrumental line shape $\left(3.2 \%, 0.0005 \mathrm{~cm}^{-1}, 1 \%\right.$ and $3 \%$ assumed). The errors caused by temperature and instrumental pointing are somewhat overestimated, because the basing uncertainties of $1 \mathrm{~K}$ and $150 \mathrm{~m}$ are assumed uncorrelated and rather conservative in comparison with the estimated standard deviation resulting from the preceding retrieval of temperature and line-ofsight. The error contribution of the joint-fitted gases $\mathrm{CCl}_{4}$, HCFC-22, $\mathrm{ClONO}_{2}, \mathrm{CH}_{3} \mathrm{CCl}_{3}, \mathrm{H}_{2} \mathrm{O}$ and $\mathrm{C}_{2} \mathrm{H}_{2}$ is assumed zero.

For the tropical geolocation the total error is minimal (5\%) at the lowermost useable tangent height $(13 \mathrm{~km})$, because here the sensitivity of the retrieval is maximal, expressed by the maximum of the averaging kernel at this altitude. Due to the considerably smaller averaging kernel the error is larger at $11 \mathrm{~km}$. Towards higher altitudes, where the PAN amount declines rapidly, the total error increases to $40 \%$ at the tropopause $(17 \mathrm{~km})$ and remains above $30 \%$ in the stratosphere. The stratospheric error estimates do not approach or exceed $100 \%$, because, among other things, the smoothing error is not taken into account in our error assessment. Measurement noise increases from $3 \%$ at $13 \mathrm{~km}$ to more than $25 \%$ at the tropopause. Except for $13 \mathrm{~km}$, uncertain knowledge on the instrumental line-of-sight (LOS) is the dominant error contribution in the altitude range $10-17 \mathrm{~km}$. Further important error sources in this altitude range are the uncertainties in spectroscopic data, instrumental line shape (ILS), temperature and, above $15 \mathrm{~km}$, in the ozone vmr. The spectroscopic uncertainty is around 3\% at most altitudes, which corresponds to the assumed 1-sigma error of $3.2 \%$ of the PAN cross sections at $250 \mathrm{~K}$ (cf. Allen et al., 2005b, c). Uncertain knowledge on ILS and temperature causes errors of up to 3 and $4 \%$, respectively, in the altitude range 10 $17 \mathrm{~km}$. The error due to unknown knowledge on ozone, as calculated from the estimated standard deviation (ESD) of the pre-fitted ozone profile, is $7 \%$ at $17 \mathrm{~km}$, but decreases rapidly towards lower altitudes. At the northern midlatitude geolocation (bottom right), where considerably lower PAN amounts were detected, the total error amounts to 14-20\% between 7 and $12 \mathrm{~km}$. Towards lower altitudes the total error increases strongly up to $75 \%$ at $5 \mathrm{~km}$ because of decreasing sensitivity of the retrieval (cf. Fig. 2, middle right). Due to declining PAN amounts the error increases up to $30 \%$ in the lower stratosphere. The main error component below $9 \mathrm{~km}$ is the uncertainty in LOS and above $9 \mathrm{~km}$ the noise error, the latter ranging from $5 \%$ at $8 \mathrm{~km}$ to $25 \%$ in the stratosphere. Further major error components are the same as at the East African location. The upper tropospheric total errors derived here are considerably smaller than the natural variability of PAN, which, e.g., in a compilation given by Roberts et al. (2004) ranges from 20 to 700 pptv. 

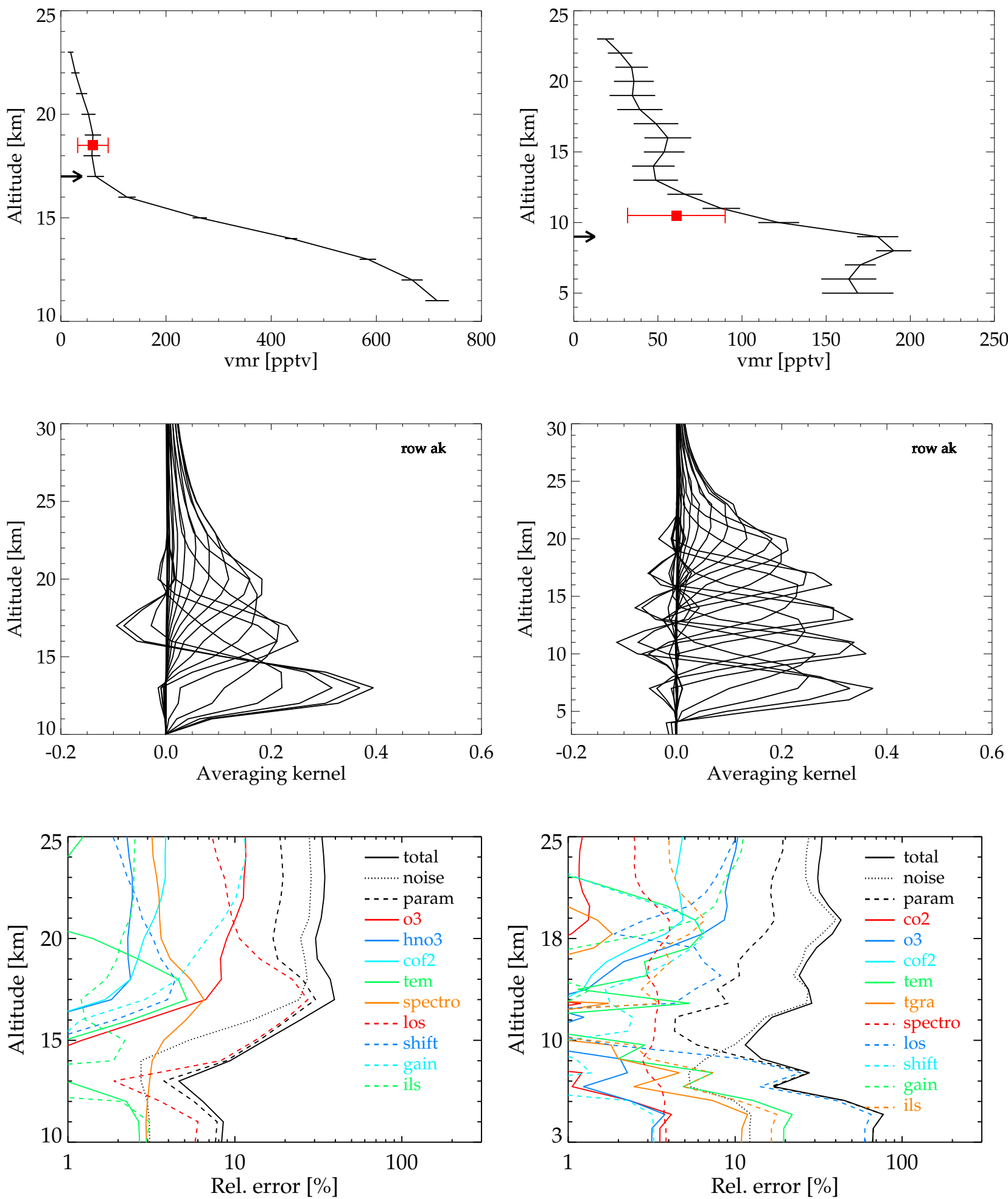

Fig. 2. Left: (top) PAN vmr-profile measured by MIPAS on 21 October, 2003, in polluted air masses over Eastern Africa (12.9 $\left.{ }^{\circ} \mathrm{S}, 37.2^{\circ} \mathrm{E}\right)$; due to cloud-contamination no PAN data are available from below $11 \mathrm{~km}$; the error bars represent the noise error; the black arrow indicates the tropopause height and the red square the average PAN amount in the lowermost stratosphere given by Singh et al. (2000b) along with the scatter of the dataset; (middle) rows of the respective averaging kernel plotted versus altitude; (bottom) total retrieval error (solid black line), noise error (dotted black line), total parameter error (dashed black line), and contributions of various other error sources (see legend, detailed explanation in Sect. 3). Right: Same as left but for a geolocation from the same orbit at northern midlatitudes $\left(51.4^{\circ} \mathrm{N}, 153.7^{\circ} \mathrm{W}\right)$. 

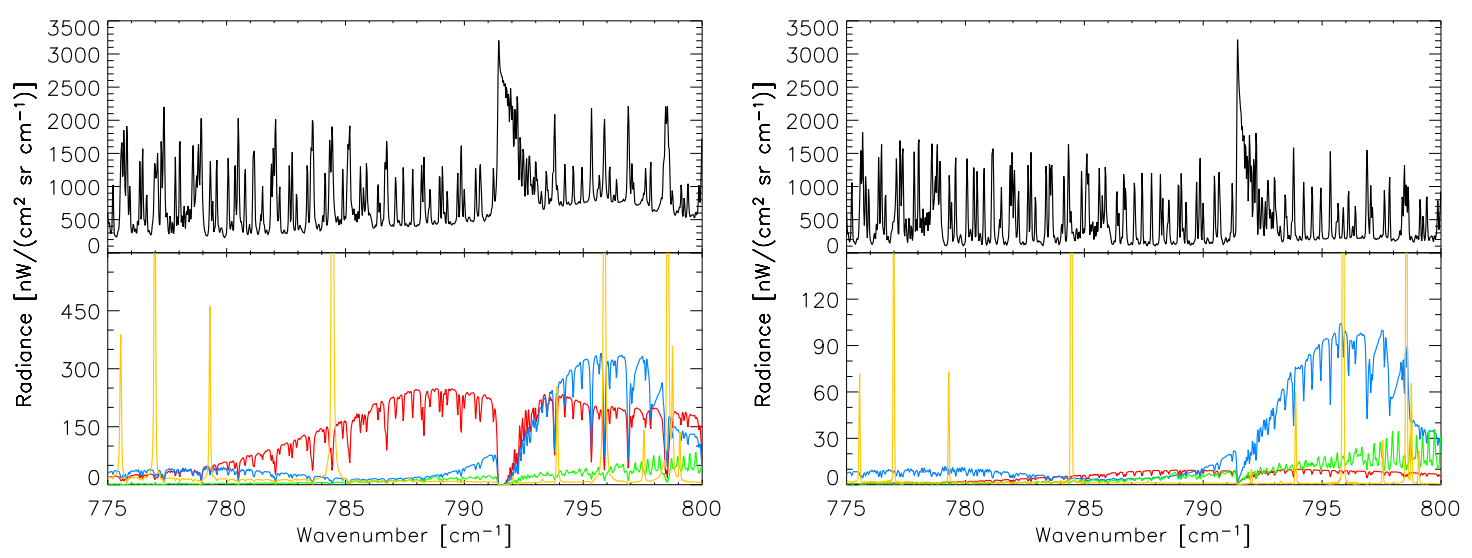

Fig. 3. Left: Modelled spectrum (black) and contributions of fitted PAN (red), $\mathrm{CCl}_{4}$ (blue), $\mathrm{HCFC}-22$ (green) and $\mathrm{H}_{2} \mathrm{O}$ (brown) for $13 \mathrm{~km}$ altitude at an East-African geolocation $\left(12.9^{\circ} \mathrm{S}, 37.2^{\circ} \mathrm{E}\right)$, where high PAN amounts of 600 pptv were retrieved. The contributions of PAN, $\mathrm{CCl}_{4}, \mathrm{HCFC}-22$ and $\mathrm{H}_{2} \mathrm{O}$ are the differences between model spectra with and without the respective gas. The top ends of the $\mathrm{H}_{2} \mathrm{O}$ lines are cut to zoom the broadband contributors. Right: Same as left, but for $19 \mathrm{~km}$ altitude.

An additional error source is the fact that the lowest laboratory temperature, for which PAN cross sections have been determined is $250 \mathrm{~K}$, whereas the upper tropospheric temperature often is considerably lower, e.g. $210 \mathrm{~K}$ at $13 \mathrm{~km}$ altitude at the East African geolocation. To estimate the possible bias resulting from this discrepancy, test retrievals were performed using the PAN cross section data sets for $273 \mathrm{~K}$ or $295 \mathrm{~K}$ only. Thereby the retrieved PAN amount at this geolocation, which due to the low temperatures had been evaluated using the cross sections for $250 \mathrm{~K}$ in the standard retrieval, increased by $13 \%$ and $26 \%$ at $13 \mathrm{~km}$ altitude, respectively. Provided that this linear dependence on temperature maps to laboratory PAN cross sections actually required for colder upper tropospheric temperatures, this would mean that the retrieval overestimates the "true" PAN amount at $13 \mathrm{~km}$ at this geolocation by $23 \%$. For a general estimation of this effect, average temperatures were calculated for the southern hemispheric area of high PAN amounts (cf. Sect. 5), which were 247, 236, 221, 209 and $199 \mathrm{~K}$ for the altitudes of 8, 10, 12, 14 and $16 \mathrm{~km}$. Under the assumption of linearity this means that the retrieved PAN amounts at these altitudes would have to be reduced by $2,8,14,19$ and $23 \%$, respectively.

Figure 3 shows the modelled spectrum and the retrieved signatures of PAN, $\mathrm{CCl}_{4}, \mathrm{HCFC}-22$ and $\mathrm{H}_{2} \mathrm{O}$ for the East African geolocation at tangent altitudes of $13 \mathrm{~km}$ (left) and $19 \mathrm{~km}$ (right). To maintain clarity the weak signatures of the other joint-fit parameters $\mathrm{ClONO}_{2}, \mathrm{CH}_{3} \mathrm{CCl}_{3}$ and $\mathrm{C}_{2} \mathrm{H}_{2}$ are not shown. At $13 \mathrm{~km}$ PAN exhibits a broadband signature of up to more than $200 \mathrm{nW} /\left(\mathrm{cm}^{2} \mathrm{srcm}^{-1}\right.$ ) (bottom left). The broadband structures of $\mathrm{CCl}_{4}$ and HCFC-22 are mainly interfering between 792 and $800 \mathrm{~cm}^{-1}$, but only little at lower wavenumbers, which enables a separation of the PAN signal. At $19 \mathrm{~km}$ the signature of PAN has decreased to $10 \mathrm{nW} /\left(\mathrm{cm}^{2} \mathrm{srcm}^{-1}\right)$ (bottom right), which is a factor of
2 lower than the instrumental NESR and also lower than the contributions of $\mathrm{CCl}_{4}$ and HCFC-22. Although the signal-tonoise ratio is enhanced by the extension of the low PAN signature over a considerable number of gridpoints, this shows that the retrieved stratospheric PAN amounts have a large uncertainty.

\section{Sensitivity tests}

To check the retrieved PAN amounts we investigated, if the measured MIPAS spectra can be modelled just as well by complete neglect of PAN. Figure 4 (left) shows the MIPAS spectrum from $13 \mathrm{~km}$ altitude obtained on 21 October 2003 on orbit 8585 at the above presented East African geolocation $\left(12.9^{\circ} \mathrm{S}, 37.2^{\circ} \mathrm{E}\right)$, where a high PAN vmr of $600 \mathrm{pptv}$ was retrieved. Further it contains fitted spectra and residuals resulting from retrieval with and without inclusion of PAN, i.e. assuming a PAN-free atmosphere in the latter case and retrieval of the joint-fit gases only. The residuals clearly show that the fit without consideration of PAN is much worse than the adjustment with modelling of PAN, confirming the large PAN amount retrieved at this altitude. This is also expressed by the RMS deviation between measured and modelled spectra, which is reduced from $41.2 \mathrm{nW} /\left(\mathrm{cm}^{2} \mathrm{srcm}^{-1}\right)$ for the retrieval without PAN to $26.9 \mathrm{nW} /\left(\mathrm{cm}^{2} \mathrm{sr} \mathrm{cm}^{-1}\right)$, i.e. by $35 \%$, for the retrieval with inclusion of PAN. For comparison the result of the same test for $19 \mathrm{~km}$ altitude at the same geolocation, where a very low PAN amount of 50 pptv was retrieved, is also shown (Fig. 4, right). In this case the residuals are nearly equal (RMS of 16.82 and $16.76 \mathrm{nW} /\left(\mathrm{cm}^{2} \mathrm{srcm}^{-1}\right)$ ), indicating that retrieval without inclusion of PAN is technically almost just as good. However the comparably good fit for the PAN-free atmosphere is obtained with a slightly negative, i.e. unphysical, amount of $\mathrm{CH} 3 \mathrm{CCl}_{3}$. This phenomenon 

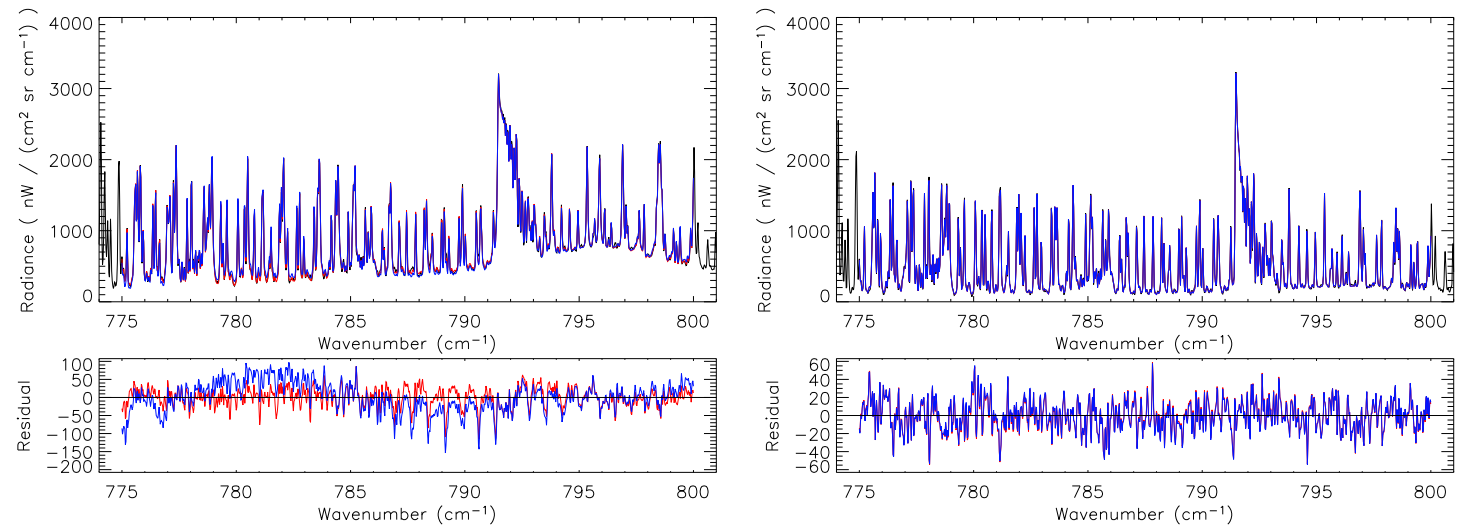

Fig. 4. Left: MIPAS spectrum from $13 \mathrm{~km}$ altitude, obtained on 21 October 2003 over Eastern Africa $\left(12.9^{\circ} \mathrm{S}, 37.2^{\circ} \mathrm{E}\right)(\mathrm{black})$, as well as fitted spectra and residuals with (red) and without (blue) inclusion of PAN. Residuals are in the same units as the radiance plots themselves. Right: Same as left, but for $19 \mathrm{~km}$ altitude.

becomes even much stronger at $13 \mathrm{~km}$, where neglect of PAN leads to large negative $\mathrm{CH}_{3} \mathrm{CCl}_{3}$ and $\mathrm{ClONO}_{2}$ amounts.

The result of this sensitivity test for the whole orbit 8585 is displayed in Fig. 5, where the ratio of the RMS-values from retrieval without and with inclusion of PAN is plotted against the retrieved PAN amount. The colour code indicates the tangent height of the respective spectra. For data points from altitudes of $16 \mathrm{~km}$ or higher the RMS-ratio is very close to unity for values below $100 \mathrm{pptv}$, indicating no sensitivity to PAN. These altitudes are at or above the tropopause, where indeed only low PAN amounts are expected. However, at lower altitudes of 7-14 km there are other points with PAN amounts below 100 pptv and larger RMS-ratios of up to 1.1. This indicates an altitude-dependent PAN significancethreshold of $\sim 100 \mathrm{pptv}$ at altitudes of $16 \mathrm{~km}$ or higher and of $\sim 60$ pptv for lower altitudes. In addition, there is a subset of datapoints, which show a linear correlation of the RMS-ratio with the retrieved PAN amounts, meaning an increasingly worse fit without consideration of PAN. For these data points, which are from altitudes between 7 and $13 \mathrm{~km}$, the RMSratio increases up to more than 1.6 for fitted PAN amounts of 200-600 pptv.

PAN detection in MIPAS/ENVISAT spectra, but following a somewhat different method, has also been reported by Allen (2005a) and by Remedios et al. (2006).

Additional tests performed in our investigation consisted in correlation between the retrieved PAN and the jointly fitted $\mathrm{CCl}_{4}$, HCFC-22 and $\mathrm{CH}_{3} \mathrm{CCl}_{3}$ amounts and showed no correlation or anticorrelation. This ensured that the broadband signatures of these species were not erroneously interpreted as PAN.
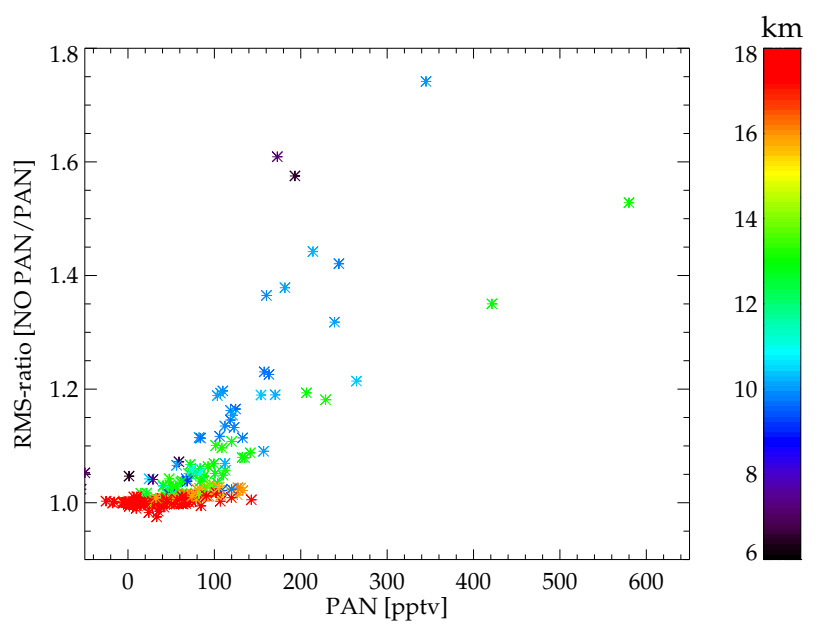

Fig. 5. Ratio of RMS-values resulting from retrievals without and with inclusion of PAN plotted versus retrieved PAN amounts for orbit 8585 of 21 October 2003. Data are color-coded with the tangent height; tangent heights higher than $18 \mathrm{~km}$ are also coded red.

\section{Discussion}

\subsection{Observed PAN distribution}

The analysed dataset consists of 150 orbits from 10 days between 4 October and 1 December, 2003, namely 4, 13, 21 and 26 October, 1, 4, 11, 21 and 24 November, and 1 December. This period covers the end of the biomass burning season in the southern hemisphere. Figure 6 exemplarily shows the global PAN distribution retrieved from single spectra for 21 October 2003 at $12 \mathrm{~km}$ altitude. The white areas, which are mainly located in the tropics and subtropics, are data gaps caused by cloud contamination. Nevertheless a contiguous area of high PAN values (250-600 pptv) extending from the 


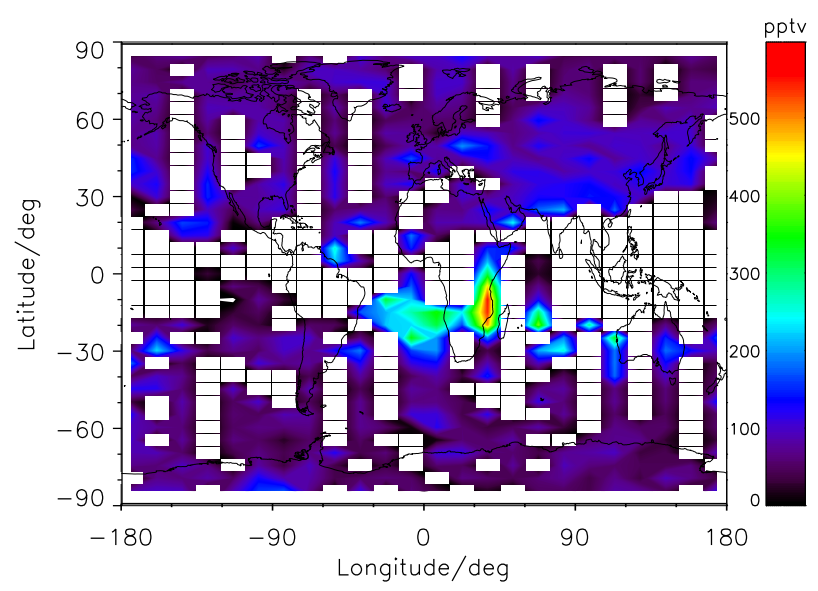

Fig. 6. Global PAN distribution on 21 October 2003 at $12 \mathrm{~km}$ altitude, obtained from MIPAS data. The white areas are data gaps due to cloud contamination.

Southern Atlantic to East Africa is visible, which we attribute to extensive biomass burning. Interrupted by data gaps, this area seems to be continued above the Southern Indian Ocean as far as Australia. To enhance the spatial data coverage we show the PAN distribution averaged over the whole period in the next two plots.

The zonal average of the whole dataset (Fig. 7) exhibits clear differences between the northern and southern hemispheric PAN distribution. In the southern hemisphere there is a large plume containing elevated PAN amounts of more than $100 \mathrm{pptv}$ between the equator and about $50^{\circ} \mathrm{S}$ in the altitude range $7-15 \mathrm{~km}$, which is obviously caused by biomass burning. Maximum values of more than $200 \mathrm{pptv}$ are between $20^{\circ} \mathrm{S}$ and $40^{\circ} \mathrm{S}$ at altitudes from 7 to $10 \mathrm{~km}$. There is another, but much more restricted, region of elevated PAN amounts in the northern hemispheric tropics, which contains maximum PAN amounts of 100-150 pptv. No data are available in the northern tropics below $8 \mathrm{~km}$ due to permanent cloud contamination of the MIPAS spectra. Further there are also elevated PAN amounts throughout the northern hemispheric mid and high latitudes, decreasing from $150 \mathrm{pptv}$ at $7 \mathrm{~km}$ to $75 \mathrm{pptv}$ at $11 \mathrm{~km}$. The major reason for these values is probably industrial pollution. However, we cannot exclude any other pollution source like boreal forest fires. In comparison to the northern hemisphere, the upper tropospheric PAN values at southern high latitudes, which are much less industrially polluted, are much lower, namely between $75 \mathrm{pptv}$ at high midlatitudes and $25 \mathrm{pptv}$ above the Antarctic. At stratospheric altitudes above $15 \mathrm{~km}$ the situation is reversed. Here, obviously due to beginning subsidence over the Arctic, the northern hemispheric mid and high latitude PAN amounts are lower than those from the southern hemisphere.

Figure 8 shows the averaged global PAN distribution at $8,10,12$ and $16 \mathrm{~km}$ altitude. At $8 \mathrm{~km}$ there are still large data gaps in the tropics due to cloud-contamination. The

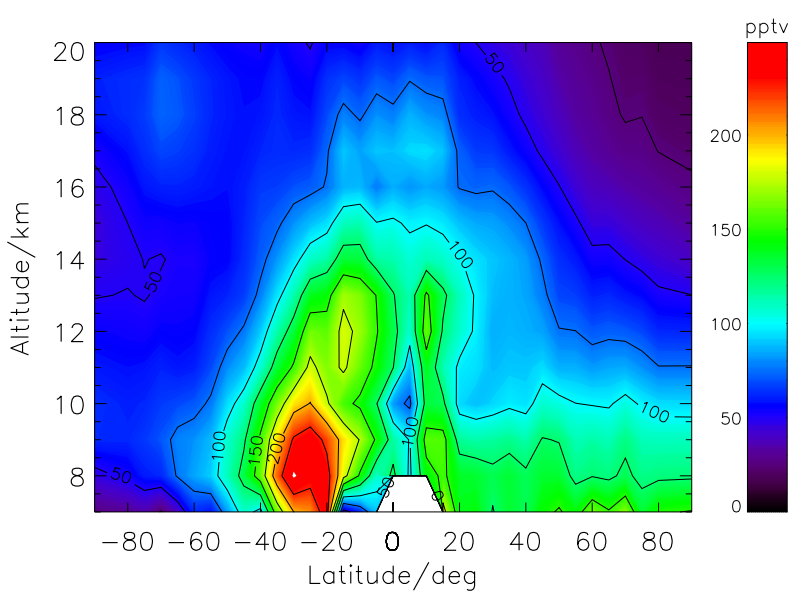

Fig. 7. Latitudinal PAN distribution, averaged zonally and over 10 days between 4 October and 1 December, 2003.

most prominent feature is a contiguous band of high PAN amounts in the southern hemispheric tropics and subtropics, which extends from the tropical and subtropical Atlantic over Southern Africa, the Southern Indian Ocean and Australia as far as to the West Pacific. The PAN values in this band are generally between 200 and 300 pptv and increase up to 500 pptv above Southern Africa and the adjacent Indian Ocean. The high PAN amounts above the Western Indian Ocean are represented by 15 individual profiles. As already mentioned above, we attribute this feature to southern hemispheric biomass burning. In the northern hemispheric subtropics, a more restricted area of elevated PAN is visible at $8 \mathrm{~km}$, extending from the African Sahel zone to India and, possibly strengthened by additional sources of PAN, further northeast above China and the Chinese Sea. At $10 \mathrm{~km}$ high PAN values appear above the whole southern and eastern Africa. At $12 \mathrm{~km}$ the area of high southern hemispheric PAN amounts does not extend so far east and ends at the West Australian coast. However, high PAN amounts of 400 500 pptv are now visible above North-East Brasil, i.e. in an area which was masked by clouds below. At $16 \mathrm{~km}$ altitude, where deterioration by clouds has mostly disappeared and the global coverage is nearly complete, the highest PAN amounts of up to 200 pptv cover an area extending from tropical Brasil above the Southern Atlantic and tropical Africa to the Southern Indian Ocean. Like in Fig. 7, the northern mid and high latitude PAN values are lower than those from the southern hemisphere.

In order to check on a qualitative basis, if the observed southern hemispheric tropical and subtropical PAN distribution can be caused by biomass burning, fire counts of the Tropical Rainfall Measuring Mission (TRMM) satellite (Giglio et al., 2000) were inspected for the time period 25 September until 1 December 2003. Indeed, numerous fire count clusters were found in South America, Central and 

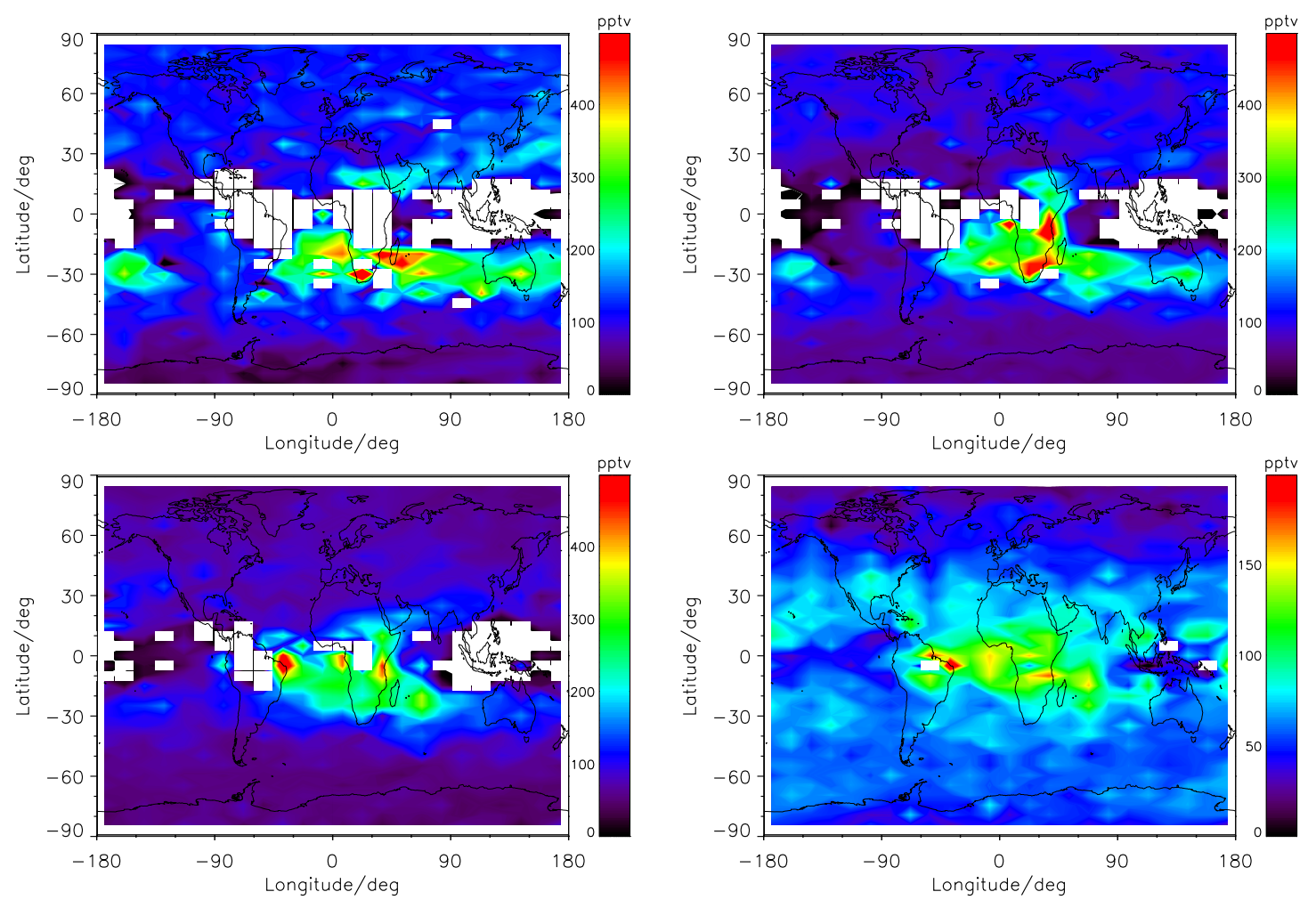

Fig. 8. Global PAN distribution at $8,10,12$ and $16 \mathrm{~km}$ altitude (top left to bottom right) averaged over 10 days between 4 October and 1 December, 2003. The white areas are data gaps due to cloud contamination.

Southern Africa and in Australia over the whole period, indicating intensive biomass burning (http://tsdis.gsfc.nasa. gov/tsdis/Fire/fireintro.html). This is also confirmed by fire counts of the Moderate Resolution Imaging Spectroradiometer (MODIS) experiment on the Terra satellite published by Edwards et al. (2006, Fig. 5a). As mentioned in Sect. 1, a more detailed and quantitative investigation of the biomass burning plume by combined analysis of several pollutants and trajectory calculations starting above the observed fire count clusters will be presented in a subsequent paper.

Figure 9 shows daily averages of the PAN values in an area containing the southern hemispheric plume (left) and from the same latitude band but from a much less polluted area above the Central and Eastern Pacific (right) at 8, 12, 16 and $20 \mathrm{~km}$ altitude. Comparison of both plots shows that the PAN values in the area containing the biomass burning plume are strongly enhanced at 8 and $12 \mathrm{~km}$ and moderately elevated at $16 \mathrm{~km}$ throughout the observation period, which basically justifies the temporal averaging performed above. At $8 \mathrm{~km}$ the PAN amounts in the plume range from 200 to $370 \mathrm{pptv}$, whereas they are around 200 and $80 \mathrm{pptv}$ at 12 and $16 \mathrm{~km}$. The corresponding values above the Pacific are much lower, about 130, 90 and $60 \mathrm{pptv}$, respectively. At $8 \mathrm{~km}$ altitude these PAN values seem also to be moderately enhanced. As mentioned above, the stratospheric PAN amounts from
$20 \mathrm{~km}$ are only little significant, but exhibit approximately the same values in both areas.

\subsection{Correlation of southern hemispheric PAN with joint- fitted $\mathrm{C}_{2} \mathrm{H}_{2}$}

Contrary to PAN the joint-fitted trace gas acetylene $\left(\mathrm{C}_{2} \mathrm{H}_{2}\right)$ exhibits narrow transition lines in MIPAS spectra (e.g. a well separated line at $776.1 \mathrm{~cm}^{-1}$ ), which can not be misinterpreted by other continuum-like structures. Since $\mathrm{C}_{2} \mathrm{H}_{2}$ is another, although not unique, product of biomass burning (Singh et al., 1996), it is suited for a cross-check of the PAN amounts retrieved in the southern hemispheric tropics and subtropics. In Fig. 10 the PAN and $\mathrm{C}_{2} \mathrm{H}_{2}$ data from the latitude band $0^{\circ}$ to $40^{\circ} \mathrm{S}$, i.e. from the biomass burning zone and the adjacent background region, are plotted against each other for the altitude region $10-16 \mathrm{~km}$. The high correlation between both datasets $(r=0.79)$ confirms the measured southern hemispheric PAN distribution. The slightly negative $\mathrm{C}_{2} \mathrm{H}_{2}$ values are mainly associated with PAN values below 100 pptv from altitudes of $15-16 \mathrm{~km}$, which are anyway only little significant (cf. Sect. 4). 

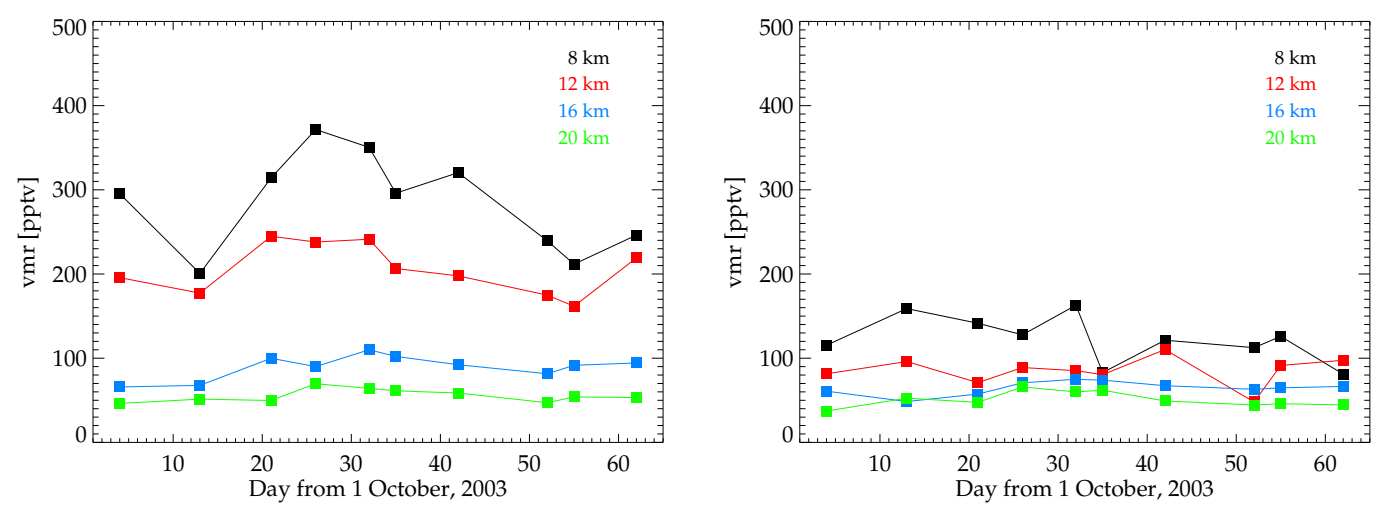

Fig. 9. Left: Daily averages of PAN amounts measured in the biomass burning zone $\left(0^{\circ}-30^{\circ} \mathrm{S}\right.$ and $\left.60^{\circ} \mathrm{W}-135^{\circ} \mathrm{E}\right)$ at $8 \mathrm{~km}(\mathrm{black}), 12 \mathrm{~km}$ (red), $16 \mathrm{~km}$ (blue) and $20 \mathrm{~km}$ altitude (green). Right: Same as left, but for an adjacent background zone above the South Pacific $\left(0^{\circ}-30^{\circ} \mathrm{S}\right.$, $\left.90^{\circ} \mathrm{W}-180^{\circ} \mathrm{W}\right)$.

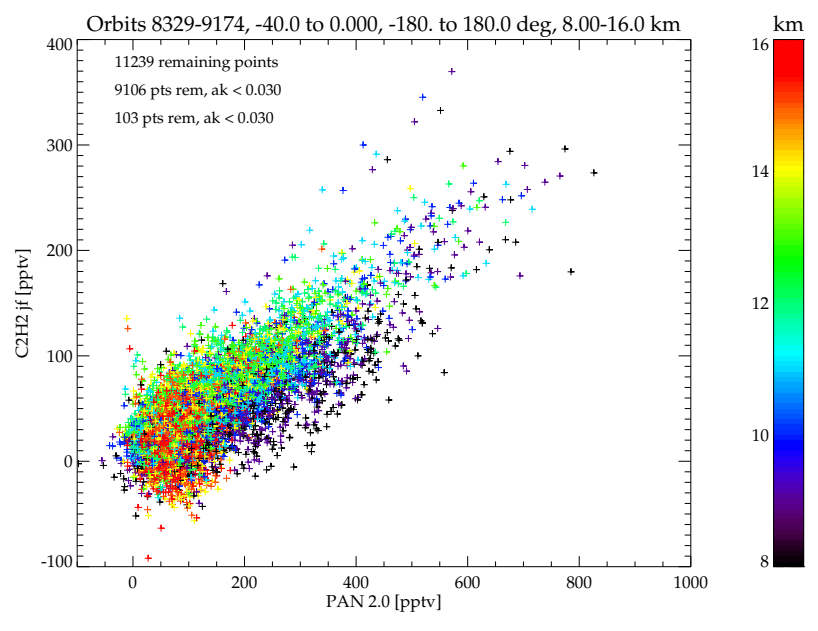

Fig. 10. Correlation between $P A N$ and joint-fitted $\mathrm{C}_{2} \mathrm{H}_{2}$ amounts, measured by MIPAS on 10 days between 4 October and 1 December, 2003, in the latitude band $0^{\circ}$ to $40^{\circ} \mathrm{S}$ between 8 and $16 \mathrm{~km}$ altitude; correlation coefficient $r=0.79$.

5.3 Comparison with other space- and airborne measurements

The biomass burning plume detected in the MIPAS PAN distribution (cf. Fig. 8) is in reasonably good agreement with the area of enhanced CO observed by the Measurement of Pollution in the Troposphere (MOPITT) instrument on the Terra satellite (Edwards et al., 2006, Figs. 1b and 4a), which these authors also attribute to biomass burning in South America, South Africa and Australia. During the last week of September 2003 MOPITT measured a plume of elevated CO (up to $\sim 160 \mathrm{ppbv})$, which on the $275 \mathrm{hPa}(\sim 10 \mathrm{~km})$ level mainly covered tropical Brasil, the Southern tropical and subtropical Atlantic, Southern Africa as well as the Western Indian Ocean, and less distinct extended until Western Australia. During the subsequent period 1-9 October 2003, which cor- responds to the beginning of our measurement period, MOPITT observed a band of high CO total columns at $30^{\circ} \mathrm{S}$, which even circumscribed the globe.

A qualitative comparison can also be made with airborne in-situ PAN measurements performed by the NASA Global Tropospheric Experiment (GTE) in September/October 1992 over the South Atlantic and the Pacific Exploratory Mission (PEM) in September/October 1996 over the remote South Pacific (Singh et al., 1996, 2000a). These campaigns were dedicated to study the distribution of species in pollution plumes originating from biomass burning regions in South America and South Africa. Over the South Atlantic average PAN amounts of about 300 pptv were found in the altitude region $3-11 \mathrm{~km}$. This agrees well with the average of MIPAS Southern Atlantic $\left(10^{\circ} \mathrm{S}\right.$ to $\left.30^{\circ} \mathrm{S}\right)$ PAN data, which is between $330 \mathrm{pptv}$ at $8 \mathrm{~km}$ and $230 \mathrm{pptv}$ at $11 \mathrm{~km}$ (cf. Fig. 8). For the remote South Pacific these authors report average PAN values of about $60 \mathrm{pptv}$ between 5 and $11 \mathrm{~km}$ altitude, whereas the MIPAS values in this region $\left(0^{\circ}\right.$ to $30^{\circ} \mathrm{S}$ and $90^{\circ} \mathrm{W}$ to $150^{\circ} \mathrm{W}$ ) are between $115 \mathrm{pptv}$ at $8 \mathrm{~km}$ and $80 \mathrm{pptv}$ at $11 \mathrm{~km}$.

Enhanced northern hemispheric PAN as displayed in Fig. 7 and Fig. 8 (top left) has also be found by Kotchenruther et al. (2001) and Roberts et al. (2004), who report on PAN amounts of about $200 \mathrm{pptv}$ in the altitude region $6-8 \mathrm{~km}$ off the westcoast of the United States and attribute these measurements to long-range transport of industrial pollution from East-Asia. Further, Remedios et al. (2007) retrieved PAN amounts of 260-180 pptv in the altitude region 7.5$10.5 \mathrm{~km}$ from MIPAS-B2 spectra obtained over the Western Mediterranean region. Elevated PAN values at high northern latitudes as shown in Fig. 7 have also been measured by e.g. Bottenheim and Gallant (1989), who report on PAN-vmrs of up to $300 \mathrm{pptv}$ at $7 \mathrm{~km}$ altitude at $70^{\circ} \mathrm{N}$ and attribute their observations to arctic haze episodes caused by industrial pollution. 


\section{Summary and conclusions}

We have used spaceborne mid-infrared measurements of MIPAS to derive the first global upper tropospheric PAN distribution. The evaluated dataset consists of ten days covering the period 4 October to 1 December 2003. PAN was retrieved in the wavenumber region $775-800 \mathrm{~cm}^{-1}$, which covers its most prominent mid-infrared signature. Beside PAN the interfering broadband species $\mathrm{CCl}_{4}, \mathrm{HCFC}-22, \mathrm{CH}_{3} \mathrm{CCl}_{3}$ and $\mathrm{ClONO}_{2}$ as well as $\mathrm{H}_{2} \mathrm{O}$ and $\mathrm{C}_{2} \mathrm{H}_{2}$ were joint-fitted. PAN profiles were derived for the upper troposphere and lower stratosphere, with about 2.5-4.5 degrees of freedom (depending on useable tangent heights) and a height resolution of $3.5-6 \mathrm{~km}$. The total retrieval error, obtained from an analytical error analysis, ranges from 5\% for strongly enhanced tropical PAN amounts (600 pptv at $13 \mathrm{~km}$ ) to $14-20 \%$ for moderate midlatitude PAN amounts $(175 \mathrm{pptv})$ near the tropopause. The error increases up to $75 \%$ towards midlatitude lower tropospheric altitudes and to more than $30 \%$ in the lower stratosphere. An additional uncertainty results from incomplete coverage of the upper tropospheric temperatures by the PAN cross section data set used. Due to this discrepancy the "true" PAN amounts in the cold tropical upper troposphere might be overestimated by up to $\sim 30 \%$. A sensitivity test to check the retrieved PAN data showed a degradation of the fit quality for retrievals without consideration of PAN, which increased with the PAN amount obtained before. Further, this test indicated a PAN significance-threshold of $\sim 60 \mathrm{pptv}$ for altitudes up to $\sim 15 \mathrm{~km}$ and of $\sim 100 \mathrm{pptv}$ above.

The analysed period covers the end of the biomass burning season in the southern hemispheric tropics and subtropics, in which large amounts of pollutants inclusive PAN are produced, uplifted into the free troposphere and distributed over large areas. Indeed, high PAN amounts were found in the southern hemispheric tropics and subtropics in the altitude range 8 to $16 \mathrm{~km}$. At $8 \mathrm{~km}$ elevated PAN values formed a nearly worldwide band extending from Brasil over the Southern Atlantic, Central and South Africa, the Southern Indian Ocean and Australia as far as to the South Pacific, whereas they were more confined to the area between Brasil and the Western Indian Ocean at higher altitudes. The PAN amounts in this biomass burning area ranged from 200 to $500 \mathrm{pptv}$ at $8 \mathrm{~km}$ and from 100 to $200 \mathrm{pptv}$ at $16 \mathrm{~km}$. Enhanced PAN amounts were also found in a much more restricted area between northern subtropical Africa and India. The most significant PAN signal at northern hemispheric midlatitudes with values of up to $250 \mathrm{pptv}$ was detected in an adjacent area extending from China into the Chinese Sea. The average mid and high latitude PAN values at $8 \mathrm{~km}$ altitude were $125 \mathrm{pptv}$ in the northern and between 75 and 50 pptv in the southern hemisphere.

During the analysed period numerous fire count clusters were observed in the southern hemispheric tropics and subtropics by the TRMM satellite. Further, the southern hemi- spheric PAN distribution is well correlated with the jointfitted $\mathrm{C}_{2} \mathrm{H}_{2}$, which is another pollutant produced by biomass burning, and there is good agreement with the $\mathrm{CO}$ distribution measured by the MOPITT experiment in late September and early October 2003. On average, the retrieved PAN amounts are also consistent to airborne PAN measurements performed during the southern hemispheric biomass burning periods of 1992 and 1996. These correspondencies confirm the southern hemispheric PAN distribution observed by MIPAS and its characteristics as biomass burning plume. A more detailed investigation of this plume by combined analysis of several pollutants will be given in a subsequent paper.

Acknowledgements. The authors like to thank the European Space Agency for giving access to MIPAS level-1 data. Meteorological analysis data have been provided by ECMWF. The IMK team has partially been supported by funds of the IMACCO project (virtual institute).

Edited by: P. Hartogh

\section{References}

Allen, G.: The infrared remote sensing of peroxyacetyl nitrate in the upper troposphere, Ph.D. thesis, University of Leicester, http: //www.leos.le.ac.uk/publications, 2005a.

Allen, G., Remedios, J. J., Newnham, D. A., Smith, K. M., and Monks, P. S.: Improved mid-infrared cross-sections for peroxyacetyl nitrate (PAN) vapour, Atmos. Chem. Phys., 5, 47-56, 2005b.

Allen, G., Remedios, J. J., and Smith, K. M.: Low temperature midinfrared cross-sections for peroxyacetyl nitrate (PAN) vapour, Atmos. Chem. Phys., 5, 3153-3158, 2005c

Beine, H. J. and Krognes, T.: The seasonal cycle of peroxyacetyl nitrate in the European Arctic, Atmos. Environ., 34, 933-940, 2000.

Bottenheim, J. W. and Gallant, A. J.: PAN over the Arctic; observations during AGASP-2 in April 1986, J. Atmos. Chem., 9, 301-316, 1989.

Edwards, D. P., Emmons, L. K., Gille, J. C., Chu, A., Attié J.-L., Giglio, L., Wood, S. W., Haywood, J., Deeter, M. N., Massie, S. T., Ziskin, D. C., and Drummond, J. R.: Satellite-observed pollution from Southern Hemisphere biomass burning, J. Geophys. Res., 111, D14312, doi:10.1029/2005JD006655, 2006.

European Space Agency: Envisat, MIPAS An instrument for atmospheric chemistry and climate research, ESA Publications Division, ESTEC, P.O. Box 299, 2200 AG Noordwijk, The Netherlands, SP-1229.

Fischer, H. and Oelhaf, H.: Remote sensing of vertical profiles of atmospheric trace constituents with MIPAS limb-emission spectrometers, Appl. Opt., 35(16), 2787-2796, 1996.

Friedl-Vallon, F., Maucher, G., Kleinert, A., Lengel, A., Keim, C., Oelhaf, H., Fischer, H., Seefeldner, M., and Trieschmann, O.: Design and characterisation of the ballon-borne Michelson Interferometer for Passive Atmospheric Sounding (MIPAS-B2), Appl. Opt., 43(16), 3335-3355, 2004.

Gaffney, J. S., Marley, N. A., Cunningham, M. M., and Doskey, P. V.: Measurements of peroxyacyl nitrates (PANS) in Mexico 
City: implications for megacity air quality impacts on regional scales, Atmos. Environ., 33, 5003-5012, 1999.

Giglio, L., Kendall, J. D., and Tucker, C. J.: Remote sensing of fires with the TRMM VIRS, Int. J. Rem. Sens., 21, 203-207, 2000.

Glatthor, N., von Clarmann, T., Fischer, H., Funke, B., Grabowski, U., Höpfner, M., Kellmann, S., Kiefer, M., Linden, A., Milz, M., Steck, T., Stiller, G. P., Mengistu Tsidu, G., and Wang, D.Y: Spaceborne $\mathrm{ClO}$ observations by the Michelson Interferometer for Passive Atmospheric Sounding (MIPAS) before and during the Antarctic major warming in September/October 2002, J. Geophys. Res., 109, D11307, doi:10.1029/2003JD004440, 2004.

Glatthor, N., von Clarmann, T., Fischer, H., Funke, B., Gil-López, S., Grabowski, U., Höpfner, M., Kellmann, S., Linden, A., López-Puertas, M., Mengistu Tsidu, G., Milz, M., Steck, T., Stiller, G. P, and Wang, D.-Y.: Retrieval of stratospheric ozone profiles from MIPAS/ENVISAT limb emission spectra: a sensitivity study, Atmos. Chem. Phys., 6, 2767-2781, 2006, http://www.atmos-chem-phys.net/6/2767/2006/.

Höpfner, M., von Clarmann, T., Fischer, H., Funke, B., Glatthor, N., Grabowski, U., Kellmann, S., Kiefer, M., Linden, A., Mengistu Tsidu, G., Milz, M., Steck, T., Stiller, G. P., and Wang, D.-Y: First spaceborne observations of Antarctic stratospheric $\mathrm{ClONO}_{2}$ recovery: Austral spring 2002, J. Geophys. Res., 109(D11), D11308, doi:10.1029/2004JD004609, 2004.

Horowitz, L. W., Walters, S., Mauzerall, D. L., Emmons, L. K., Rasch, P. J., Granier, C., Tie, X., Lamarque, J.-F., Schultz, M. G., and Brasseur, G. P.: A global simulation of tropospheric ozone and related tracers: Description and evaluation of MOZART, version 2, J. Geophys. Res., 108(D24), 4784, doi:10.1029/2002JD002853, 2003.

Jacobi, H.-W. and Schrems, O.: Peroxyacetyl nitrate (PAN) distribution over the South Atlantic Ocean, Phys. Chem. Chem. Phys., 1, 5517-5521, 1999.

Kotchenruther, R. A., Jaffe, D. A., and Jaeglé, L.: Ozone photochemistry and the role of peroxyacetyl nitrate in the springtime northeastern Pacific troposphere: results from the Photochemical Ozone Budget of the Eastern North Pacific Atmosphere (PHOBEA) campaign, J. Geophys. Res., 106(D22), 28731$28742,2001$.

Levenberg, K.: A method for the solution of certain non-linear problems in least squares, Quart. Appl. Math., 2, 164-168, 1944.

Marquardt, D. W.: An algorithm for least-squares estimation of nonlinear parameters, J. Soc. Indust. Appl. Math., 11(2), 431441, 1963.

Nett, H., Perron, G., Sanchez, M., Burgess, A., and Mossner, P.: MIPAS inflight calibration and processor validation, in ENVISAT Calibration Review, Proc. of the European Workshop, 913 September 2002, ESTEC, Noordwijk, The Netherlands, CDROM, vol. SP-520, edited by H. Sawaya-Lacoste, ESA Publications Division, ESTEC, Postbus 299, 2200 AG Noordwijk, The Netherlands, 2002.

Remedios, J. J., Allen, G., and Waterfall, A. M.: Infra-red remote sensing of organic compounds in the upper troposphere, in: Proceedings of the First "Atmospheric Science Conference", edited by: Lacoste, H., ESA SP-628, ESA Publications Division, European Space Agency, Noordwijk, The Netherlands, 2006.

Remedios, J. J., Allen, G., Waterfall, A. M., Oelhaf, H., and Kleinert, A.: Detection of organic compound signatures in infra-red, limb emission spectra observed by the MIPAS-B2 balloon instru- ment, Atmos. Chem. Phys., 7, 1599-1613, 2007, http://www.atmos-chem-phys.net/7/1599/2007/.

Roberts, J. M., Flocke, F., Chen, G., de Gouw, J., Holloway, J. S., Hübler, G., Neuman, J. A., Nicks Jr., D. K., Nowak, J. B., Parrish, D. D., Ryerson, T. B., Sueper, D. T., Warneke, C., and Fehsenfeld, F. C.: Measurement of peroxycarboxylic nitric anhydrides (PANs) during the ITCT 2K2 aircraft intensive experiment, J. Geophys. Res., 109, D23S21, doi:10.1029/2004JD004960, 2004.

Rodgers, C. D.: Inverse Methods for Atmospheric Sounding: Theory and Practice, volume 2 of Series on Atmospheric, Oceanic and Planetary Physics, edited by: Taylor, F. W., World Scientific, 2000.

Singh, H. B.: Reactive nitrogen in the troposphere, Environ. Sci. Technol., 21(4), 320-327, 1987.

Singh, H. B., Herlth, D., Kolyer, R., Chatfield, R., Viezee, W., Salas, L. J., Chen, Y., Bradshaw, J. D., Sandholm, S. T., Talbot, R., Gregory, G. L., Anderson, B., Sachse, G. W., Browell, E., Bachmeier, A. S., Blake, D. R., Heikes, B., Jacob, D., and H. E. Fuelberg: Impact of biomass burning emissions on the composition of the South Atlantic troposphere: Reactive nitrogen and ozone, J. Geophys. Res., 101(D19), 24 203-24 219, 1996.

Singh, H. B., Viezee, W., Chen, Y., Bradshaw, J., Sandholm, S., Blake, D., Blake, N., Heikes, B., Snow, J., Talbot, R., Browell, E., Gregory, G., Sachse, G., and Vay, S.: Biomass burning influences on the composition of the remote South Pacific troposphere: analysis based on observations from PEM-Tropics-A, Atmos. Environ., 34(4), 635-644, 2000a.

Singh, H., Chen, Y., Tabazadeh, A., Fukui, Y., Bey, I., Yantosca, R., Jacob, D., Arnold, F., Wohlfrom, K., Atlas, E., Flocke, F., Blake, N., Heikes, B., Snow, J., Talbot, R., Gregory, G., Sachse, G., Vay, S., and Kondo, Y.: Distribution and fate of selected oxygenated organic species in the troposphere and lower stratosphere over the Atlantic, J. Geophys. Res., 105(D3), 3795-3805, 2000b.

Steck, T.: Methods for determining regularization for atmospheric retrieval problems, Appl. Opt., 41(9), 1788-1797, 2002.

Stephens, E. R., Hanst, P. L., Dörr, R. C., and Scott, W. E.: Reactions of nitrogen dioxide and organic compounds in air, Ind. Eng. Chem., 48, 1498-1504, 1956.

Stiller, G. P. (Ed.): The Karlsruhe Optimized and Precise Radiative transfer Algorithm (KOPRA), Institut für Meteorologie und Klimaforschung, Forschungszentrum Karlsruhe GmbH, 2000.

Temple, P. J. and Taylor, O. C.: World-wide ambient measurements of PAN and implications for plant injury, Atmos. Environ., 17, 1583-1588, 1983.

von Clarmann, T. and Echle, G.: Selection of optimized microwindows for atmospheric spectroscopy, Appl. Opt., 37(33), 76617669, 1998.

von Clarmann, T., Ceccherini, S., Doicu, A., Dudhia, A., Funke, B., Grabowski, U., Hilgers, S., Jay, V., Linden, A., LópezPuertas, M., Martín-Torres, F.-J., Payne, V., Reburn, J., Ridolfi, M., Schreier, F., Schwarz, G., Siddans, R., and Steck, T.: A blind test retrieval experiment for infrared limb emission spectrometry, J. Geophys. Res., 108(D23), 4746, doi:10.1029/2003JD003835, 2003a.

von Clarmann, T., Fischer, H., Funke, B., Glatthor, N., Grabowski, U., Höpfner, M., Kellmann, S., Kiefer, M., Linden, A., Mengistu Tsidu, G., Milz, M., Steck, T., Stiller, G. P., Wang, D.-Y., GilLópez, S., and López-Puertas, M.: Retrieval of temperature and 
tangent altitude pointing from limb emission spectra recorded from space by the Michelson Interferometer for Passive Atmospheric Sounding (MIPAS), J. Geophys. Res., 108(D23), 4736, doi:10.1029/2003JD003602, 2003b. 